\section{Stability of Extemporaneously Compounded Clonidine in Glass and Plastic Bottles and Plastic Syringes}

Clonidine suspensions to attenuate opioid withdrawal symptoms in children require low doses and dilute concentrations. ${ }^{1}$ To the authors' knowledge, only one study on the stability of clonidine $0.01 \mathrm{mg} / \mathrm{L}$ suspensions (in OraBlend vehicle) has been published. ${ }^{2}$ The purpose of the current study was to evaluate whether extemporaneously prepared clonidine suspensions $(0.010 \mathrm{mg} / \mathrm{mL})$ are physically and chemically stable in other commercially available vehicles, specifically Oral Mix and Oral Mix SF, at $25^{\circ} \mathrm{C}$ and $4^{\circ} \mathrm{C}$ for up to 91 days.

Stock clonidine suspensions $(0.010 \mathrm{mg} / \mathrm{mL})$ were prepared by crushing commercially available clonidine $0.1-\mathrm{mg}$ tablets (Novopharm, Toronto, Ontario; lot 35204900A, expiry October 2015) in Oral Mix and Oral Mix SF (Medisca Inc, Plattsburgh, New York; lot 1074/A, expiry February 2015; lot 1071/A, expiry January 2015, respectively). Each suspension was divided among 6 amber glass bottles (Richards Distribution, Richmond, British Columbia), 6 amber polyethylene terephthalate bottles (Richards Distribution) and twenty-five 5-mL amber oral plastic syringes (PreciseDose Dispenser System, Medisca Inc; lot 46959/C). For each suspension, 3 glass and 3 plastic bottles were kept at $25^{\circ} \mathrm{C}$ and 3 glass and 3 plastic bottles at $4^{\circ} \mathrm{C}$. All syringes were kept at $25^{\circ} \mathrm{C}$.

All samples were visually examined for colour, taste, odour, and ease of resuspension at time of preparation, every week up to 21 days, and then every 2 weeks up to 91 days. On each study day, one aliquot $(3 \mathrm{~mL})$ from each bottle and the contents of 3 syringes from each group were collected to determine $\mathrm{pH}$. Immediately thereafter, $1.5-\mathrm{mL}$ sample aliquots from each bottle or syringe were transferred to airtight polypropylene freezer vials (VWR International, Mississauga, Ontario) and stored at $-85^{\circ} \mathrm{C}$ until analysis by a validated, stability-indicating high-performance liquid chromatography (HPLC) - ultraviolet detection method.

Stock solutions $(0.010 \mathrm{mg} / \mathrm{mL})$ were prepared in HPLCgrade water (Fisher Scientific, Whitby, Ontario; lot 131258) from clonidine hydrochloride powder (Sigma-Aldrich, Oakville, Ontario; lot 110M1256V). Lidocaine (Alveda Pharmaceuticals Inc, Toronto, Ontario; lot 30399, expiry September 2016) diluted in HPLC-grade water (to $0.050 \mathrm{mg} / \mathrm{mL}$ ) served as the internal standard.

The HPLC instrumentation (Waters Alliance System model 2690, Waters Corporation, Mississauga, Ontario) consisted of a delivery pump, automatic 200- $\mu \mathrm{L}$ injector, XTerra C18-RP 4.6 $\times 150 \mathrm{~mm}$ column (Waters Corporation; lot 0180333231061), XTerra C18 $3.9 \times 20$ mm guard column (Waters Corporation; lot 0180333261), and ultraviolet dual-absorbance detector (model 2487; Waters Alliance System), set at $205 \mathrm{~nm}$. The mobile-phase gradient consisted of 33\%-55\%-33\% acetonitrile (Fisher Scientific; lot 136170) and 67\%-45\%-67\% $10 \mathrm{mmol} / \mathrm{L}$ ammonium formate buffer (Sigma-Aldrich; lot BCBJ-6906V) at $\mathrm{pH} 10.0$ and $25^{\circ} \mathrm{C}$. All solvents were HPLC-grade and filtered. The flow rate was $1.0 \mathrm{~mL} / \mathrm{min}$. Assay and degradation methods were developed in the authors' laboratory on the basis of previous work. $^{2-4}$

The calibration curve $(0.0010,0.0014,0.0018,0.0022$, 0.0026 , and $0.0028 \mathrm{mg} / \mathrm{mL}$ ) encompassed diluted test concentrations of clonidine (nominally $0.0020 \mathrm{mg} / \mathrm{mL}$ ) and was generated by least-squares regression of the peak area ratio of clonidine to lidocaine and the concentration of each clonidine standard. Acceptable coefficients of variation for precision were defined as less than $10 \%$ and the limits for accuracy as greater than $90 \%$.

On the day of analysis, each study sample (nominal concentration $0.010 \mathrm{mg} / \mathrm{mL}$ ) was thawed and vortex-mixed for $10 \mathrm{~s}$. A $0.400-\mathrm{mL}$ aliquot was diluted with $0.600 \mathrm{~mL}$ of HPLC-grade water and centrifuged at $5200 \mathrm{rpm}$ for $5 \mathrm{~min}$. Then, $0.500 \mathrm{~mL}$ of supernatant was mixed with $0.100 \mathrm{~mL}$ of lidocaine $(0.050 \mathrm{mg} / \mathrm{mL})$ and the volume was adjusted to $1 \mathrm{~mL}$ with HPLC-grade water, with final nominal concentrations $0.0020 \mathrm{mg} / \mathrm{mL}$ (clonidine) and $0.0050 \mathrm{mg} / \mathrm{mL}$ (lidocaine). Each sample was filtered via $0.45-\mu \mathrm{m}$ Acrodisc microfilter (Waters Corporation; lot 21829235$)$ before injection $(75-\mu \mathrm{L})$ onto the column.

Accelerated degradation of clonidine was achieved as follows. Clonidine suspensions $(0.0010 \mathrm{mg} / \mathrm{mL})$ in Oral Mix and Oral Mix SF were prepared (without internal standard) from stock solution $(0.020 \mathrm{mg} / \mathrm{mL})$. Aliquots were mixed (v/v) with $2 \mathrm{~N}$ sodium hydroxide, $2 \mathrm{~N}$ hydrochloric acid, or $30 \%$ hydrogen peroxide, then vortex-mixed and incubated for $2 \mathrm{~h}$ at $90^{\circ} \mathrm{C}$. Samples were cooled to room temperature, $\mathrm{pH}$ was adjusted to 4.5, and concentration was adjusted with HPLC-grade water to $0.0020 \mathrm{mg} / \mathrm{mL}$. Samples were filtered and injected onto the column.

Regression analysis demonstrated linearity, with $r^{2}$ of 0.996 or above $(n=4)$. Intraday and interday coefficients of variation were $1.80 \%$ and $4.47 \%$, respectively, for the $0.0010 \mathrm{mg} / \mathrm{mL}$ solution; $2.15 \%$ and $3.02 \%$, respectively, for the $0.0016 \mathrm{mg} / \mathrm{mL}$ solution; $1.36 \%$ and $1.59 \%$, respectively, for the $0.0020 \mathrm{mg} / \mathrm{mL}$ solution; and $2.25 \%$ and $1.35 \%$, respectively, for the 
Table 1. Concentration of Clonidine in Oral Mix during 91 Days of Storage in Glass Bottles, Plastic Bottles, and Plastic Syringes at $25^{\circ} \mathrm{C}$ and in Glass and Plastic Bottles at $4^{\circ} \mathrm{C}^{*}$

Mean Concentration \pm SD $(\mathrm{mg} / \mathrm{mL})$ and Mean \% Remaining

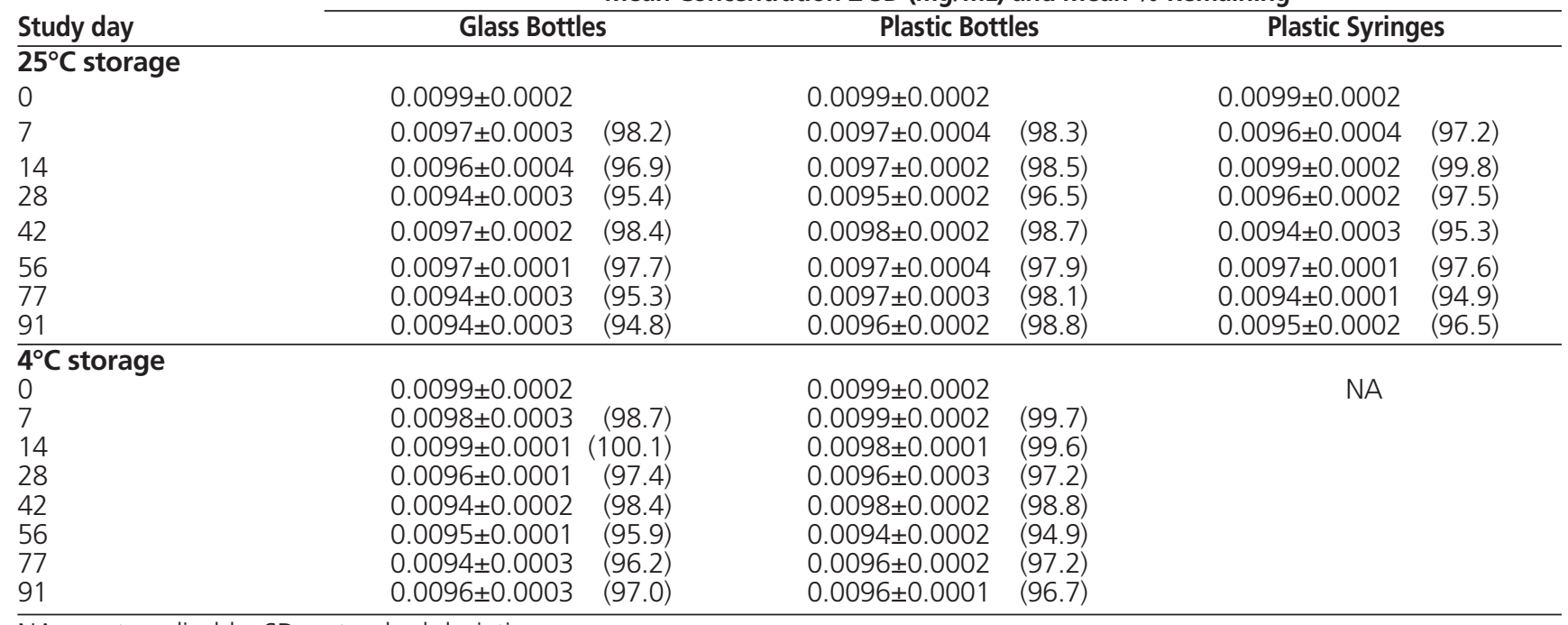

$\mathrm{NA}=$ not applicable, $\mathrm{SD}=$ standard deviation.

*Nominal concentration: $0.0100 \mathrm{mg} / \mathrm{mL}$. Mean values based on 3 samples analyzed in duplicate. Percent remaining relative to measured concentration on day 0 .

Table 2. Concentration of Clonidine in Oral Mix SF during 91 Days of Storage in Glass Bottles, Plastic Bottles, and Plastic Syringes at $25^{\circ} \mathrm{C}$ and in Glass and Plastic Bottles at $4^{\circ} \mathrm{C}^{*}$

Mean Concentration \pm SD $(\mathrm{mg} / \mathrm{mL})$ and Mean $\%$ Remaining

\begin{tabular}{|c|c|c|c|}
\hline Study day & Glass Bottles & Plastic Bottles & Plastic Syringes \\
\hline \multicolumn{4}{|c|}{$25^{\circ} \mathrm{C}$ storage } \\
\hline 0 & $0.0099 \pm 0.0002$ & $0.0099 \pm 0.0002$ & $0.0099 \pm 0.0002$ \\
\hline 7 & $0.0101 \pm 0.0007(101.2)$ & $0.0098 \pm 0.0002$ & $0.0097 \pm 0.0004$ \\
\hline 14 & $0.0101 \pm 0.0002(101.0)$ & $0.0099 \pm 0.0001(100.1)$ & $0.0097 \pm 0.0002 \quad(98.3)$ \\
\hline 28 & $0.0095 \pm 0.0001 \quad(96.0)$ & $0.0097 \pm 0.0002 \quad(98.0)$ & $0.0097 \pm 0.0002$ \\
\hline 42 & $0.0097 \pm 0.0002 \quad(98.6)$ & $0.0098 \pm 0.0001$ & $0.0098 \pm 0.0002 \quad(99.0)$ \\
\hline 56 & $0.0098 \pm 0.0002$ & $0.0099 \pm 0.0003(100.4)$ & $0.0100 \pm 0.0003$ \\
\hline 77 & $0.0097 \pm 0.0001$ & $0.0099 \pm 0.0003(100.0)$ & $0.0095 \pm 0.0001 \quad(96.9)$ \\
\hline 91 & $0.0099 \pm 0.0003(100.1)$ & $0.0099 \pm 0.0002$ & $0.0098 \pm 0.0003$ \\
\hline \multicolumn{4}{|c|}{$\overline{4^{\circ} \mathrm{C} \text { storage }}$} \\
\hline 0 & $0.0099 \pm 0.0002$ & $0.0099 \pm 0.0002$ & NA \\
\hline 7 & $0.0100 \pm 0.0001(101.8)$ & $0.0098 \pm 0.0002$ & \\
\hline 14 & $0.0097 \pm 0.0001$ & $0.0099 \pm 0.0001(100.3)$ & \\
\hline 28 & $0.0096 \pm 0.0002 \quad(97.6)$ & $0.0096 \pm 0.0001$ & \\
\hline 42 & $0.0098 \pm 0.0001$ & $0.0098 \pm 0.0001$ & \\
\hline 56 & $0.0099 \pm 0.0003(100.2)$ & $0.0099 \pm 0.0003(103.1)$ & \\
\hline 77 & $0.0097 \pm 0.0002 \quad(98.6)$ & $0.0096 \pm 0.0002$ & \\
\hline 91 & $0.0098 \pm 0.0002 \quad(99.1)$ & $0.0098 \pm 0.0002$ & \\
\hline
\end{tabular}

$\mathrm{NA}=$ not applicable, SD = standard deviation.

*Nominal concentration: $0.0100 \mathrm{mg} / \mathrm{mL}$. Mean values based on 3 samples analyzed in duplicate. Percent remaining relative to measured concentration on day 0 .

$0.0028 \mathrm{mg} / \mathrm{mL}$ solution. Mean intraday and interday accuracies ( \pm standard deviation) were $96.12 \% \pm 2.86 \%$ and $96.12 \% \pm 3.26 \%$, respectively, for the $0.0010 \mathrm{mg} / \mathrm{mL}$ solution; $97.26 \% \pm 2.13 \%$ and $98.50 \% \pm 1.74 \%$, respectively, for the $0.0016 \mathrm{mg} / \mathrm{mL}$ solution; $97.73 \% \pm 0.82 \%$ and $98.43 \% \pm 1.60 \%$, respectively, for the $0.0020 \mathrm{mg} / \mathrm{mL}$ solution; and $98.52 \% \pm 1.15 \%$ and $98.80 \% \pm 0.96 \%$, respectively, for the $0.0028 \mathrm{mg} / \mathrm{mL}$ solution. Retention times were $4.99 \mathrm{~min}$ (clonidine) and $9.11 \mathrm{~min}$ (lidocaine). No interfering peaks were generated by forced degradation of clonidine. Clonidine peaks 
decreased by $26 \%$, on average, and minor degradation peaks appeared at 4.36, 5.57 , and $9.30 \mathrm{~min}$.

Throughout the study period, the mean $\mathrm{pH}$ ranged from 4.82 to 4.89 for suspensions in Oral Mix and from 5.00 to 5.06 for suspensions in Oral Mix SF. All suspensions were easily resuspended, with no notable changes in the milky white colour; the faint, tart cherry taste; or odour.

HPLC analysis showed that all suspensions maintained more than $94 \%$ of the original concentration for 91 days (Tables 1 and 2).

In conclusion, clonidine suspensions $(0.010 \mathrm{mg} / \mathrm{mL})$ in Oral Mix and Oral Mix SF stored in amber glass bottles, plastic bottles, or oral plastic syringes at $25^{\circ} \mathrm{C}$ or in amber glass or plastic bottles at $4^{\circ} \mathrm{C}$ can be expected to remain stable for up to 91 days.

\section{References}

1. Arenas-López S, Riphagen S, Tibby SM, Durward A, Tomlin S, Davies G, et al. Use of oral clonidine for sedation in ventilated paediatric intensive care patients. Intensive Care Med. 2004;30(8):1625-9.

2. Ma C, Decarie D, Ensom MHH. Stability of clonidine suspension in oral plastic syringes. Am J Health Syst Pharm. 2014;71(8):657-61.

3. Ensom MHH, Kendrick J, Rudolph S, Decarie D. Stability of propranolol in extemporaneously compounded suspensions. Can J Hosp Pharm. 2013; 66(2):118-24.
4. Levinson ML, Johnson CE. Stability of an extemporaneously compounded clonidine hydrochloride oral liquid. Am J Hosp Pharm. 1992;49(1):122-5.

Mary H H Ensom, BS(Pharm), PharmD, FASHP, FCCP, FCSHP

Clinical Pharmacy Specialist

Diane Décarie, BSC

Research Consultant

Department of Pharmacy

Children's and Women's Health Centre of British Columbia

Vancouver, British Columbia.

Mary $\mathrm{H} \mathrm{H}$ Ensom is also a Professor in the Faculty of Pharmaceutical Sciences and Distinguished University Scholar, The University of British Columbia, Vancouver, British Columbia, and she is the Editor of the CJHP.

Funding: Funding for this project was provided as an unrestricted educational grant from Medisca Pharmaceutique Inc.

Competing interests: Other than grant support, no competing interests were declared. 